\title{
Improving the reproductive traits of turkey hens with regard to toms selection*
}

\author{
K. Wawro ${ }^{1}$, J. Jankowski ${ }^{2}$ and A. Faruga ${ }^{2}$ \\ 'Institute of Genetics and Methods of Animal Development \\ ${ }^{2}$ Department of Poultry Science, \\ University of Agriculture and Technology \\ Oczapowskiego 5, 10-718 Olsztyn, Poland
}

(Received 16 January 1995; accepted 12 April 1996)

\begin{abstract}
1210 turkey hens from generation $12\left(G_{12}\right)$ and 737 from generation $13\left(G_{13}\right)$ of the maternal female strain $\mathrm{J}-44$ were investigated. The male parents of the toms chosen to selection flocks in $\mathrm{G}_{12}$ and $G_{13}$ were evaluated by means of a selection index including reproductive performance of their female relatives: mothers, sisters and half-sisters. The hens, in turn, were selected taking into account the results of the evaluation of the value in use and breeding value of their mothers according to the SELECT system.

It has been found that the used breeding methods aiming at increasing the reproductive traits value in strain $\mathrm{J}-\mathbf{4 4}$ hens turned out to be efficient. The achieved breeding gain amounted to 10.2 of eggs, $5.0 \%$ of egg fertility and $3.5 \%$ of hatchability from fertile eggs.
\end{abstract}

KEY WORDS: turkey hens, reproductive traits, breeding methods, breeding gain

\section{INTRODUCTION}

The scope of the achieved breeding gain is directly proportional to selection intensity, genetic variability and accuracy in estimating the breeding value of the selected birds. The selection intensity is determined by the size of a breeding farm, and it can be slightly increased through an improvement of reproductive traits of birds, i.e. obtaining a larger number of progeny in each selection flock. Genetic variability usually undergoes little change from generation to generation

* The research was financed by grant No. 503679101 from the Committee for Scientific Research 
(Jankowski, 1989). Therefore, in closed turkey populations these two factors will not have a significant influence on the breeding gain achieved in successive generations. The increase in breeding gain will be dependent mainly on the accuracy of the estimating the breeding value of selected birds.

The reproductive traits of domestic maternal strain J-33 and J-44 were in the past improved by means of so called "reproductive traits indices", calculated on the basis of the yield of the female parents of selected birds (Jankowski, 1989). These indices appeared to be very efficient in the initial period of breeding work. In the female maternal strain $\mathbf{J}-44$, being improved, first of all, in terms of increasing egg production and hatchability, the breeding gain achieved by five generations amounted to $17.4 \%$ in the number of eggs, i.e. 16 eggs per hen, $11.2 \%$ in hatchability from fertile eggs and $14.5 \%$ from set eggs (Jankowski, 1989). In the next five generations $\left(G_{6}\right.$ to $\left.G_{10}\right)$ no further significant increase in the reproductive traits value was observed (Baran, 1993).

A considerable breeding gain in reproductive traits can be achieved through a similar selection of toms, which have a larger share in the formation of progeny genotypes than hens do. It results from the investigations of Wawro et al. (1993) that breeding gain in reproductive traits of turkeys can be more than twice as large when such information sources as sisters and half-sisters utility are used in addition to mothers performance.

The aim of this research was to evaluate the results of using selection indices for both sires and dams in improving reproductive traits.

\section{MATERIAL AND METHODS}

The research material was made up by the values of traits evaluated during the reproduction period of 1210 turkey hens from generation $12\left(G_{12}\right)$ and 737 hens from generation $13\left(\mathrm{G}_{13}\right)$ of the $\mathrm{J}-44$ strain. In these generations, toms for selection flocks were chosen after those sires which achieved the greatest value of the selection index. The construction of this index was presented in the paper by Wawro et al. (1993). It consists in combining, in different variants, of such information sources as: the performances of mothers (M), sisters (S) and half-sisters (SH) in the form of indices for an estimating of the breeding value (BV) of toms in terms of the following traits: the number of eggs $\left(x_{1}\right)$, fertility $\left(x_{2}\right)$ and hatchability from fertile eggs $\left(\mathrm{x}_{3}\right)$. The general index model (I) for each of the evaluated traits is as follows:

$$
\mathrm{I}_{\mathrm{i}}=\mathrm{P}_{\mathrm{i}}+\mathrm{b}_{\mathrm{Mi}}(\mathrm{Mi})+\mathrm{b}_{\mathrm{Si}}(\mathrm{Si})+\mathrm{b}_{\mathrm{SHi}}\left(\mathrm{SH}_{\mathrm{i}}\right)
$$

where: $i$ - trait $i ; P_{i}$ - population average; $b_{M} b_{S} b_{S H}$ - regression coefficients determining the degree in which a given information source contributes to 
determining the breeding value. The presented coefficients have been calculated with regard to heritability of trait $\mathrm{i}\left(\mathrm{h}_{\mathrm{i}}^{2}\right)$, the numerical force of the information source (number of sisters and half-sisters) and the average relationship coefficient within the information source, as well as the relation between the information source and the evaluated individual.

The index (I) used in the sires selection, determining their total breeding value in terms of reproductive traits $\left(\mathrm{x}_{1}, \mathrm{x}_{2}\right.$, and $\left.\mathrm{x}_{3}\right)$ has been constructed as follows:

$$
\mathbf{I}=\mathrm{s}_{1} \mathrm{I}_{1}+\mathrm{s}_{2} \mathbf{I}_{2}+\mathrm{s}_{3} \mathbf{I}_{3}
$$

where: $I_{1}-I_{3}$ stand for breeding value of an individual with regard to: number of eggs $\left(I_{1}\right)$, fertility $\left(I_{2}\right)$ and hatchability from fertile eggs $\left(I_{3}\right)$, while $s_{1}=0.60$; $\mathrm{s}_{2}=0.15$ and $\mathrm{s}_{3}=0.25$ are coefficients determining the importance of a particular trait in the final index, adopted in accordance with the turkey selection in strain J-44 (Jankowski, 1989).

The two successive turkey generations, analysed in this paper, descended as follows: $G_{12}-$ after 132 sires and 209 dams; $G_{13}$-after 74 sires and 162 dams. The rearing of the birds and reproductive utilization and feeding were carried out according to the technology developed by Faruga et al. (1989). The turkeys of both generations were kept in the same buildings with stable environmental conditions.

TABLE 1

Means $(\bar{x})$, standard deviations (s), heritability coefficients $\left(h^{2}\right)$ and dam effect $\left(c^{2}\right)$ of traits evaluated of reproduction period of J-44 strain turkey hens in generations 12 and 13

\begin{tabular}{|c|c|c|c|c|c|c|c|c|}
\hline \multirow[t]{3}{*}{ Trait } & \multicolumn{8}{|c|}{ Generation } \\
\hline & \multicolumn{4}{|c|}{$12^{*}$} & \multicolumn{4}{|c|}{13} \\
\hline & $\bar{x}$ & s & $h^{2}$ & $c^{2}$ & $\bar{x}$ & $s$ & $h^{2}$ & $c^{2}$ \\
\hline \multicolumn{9}{|c|}{ Body weight (g) at the age of: } \\
\hline-30 weeks & 8167 & 859.2 & 0.496 & -0.013 & 7739 & 700.0 & 0.413 & -0.009 \\
\hline-56 weeks & 8722 & 1118.3 & 0.668 & -0.187 & 8739 & 1000.0 & 0.471 & 0.044 \\
\hline \multicolumn{9}{|l|}{ Age of reproductive } \\
\hline maturity, days & 221.6 & 7.12 & 0.758 & -0.187 & 222.7 & 9.50 & 0.404 & -0.023 \\
\hline Number of eggs & 87.6 & 30.08 & 0.427 & -0.088 & 97.8 & 27.96 & 0.242 & 0.031 \\
\hline Number of laying days & 143.5 & 43.28 & 0.629 & -0.146 & 145.0 & 36.89 & 0.174 & 0.008 \\
\hline Egg weight, $g$ & 80.6 & 13.99 & 0.417 & 0.074 & 75.7 & 4.40 & 0.292 & 0.263 \\
\hline Egg fertility, $\%$ & 87.3 & 19.00 & 0.268 & 0.019 & 92.3 & 14.03 & 0.186 & 0.133 \\
\hline \multicolumn{9}{|l|}{ Hatchability from, $\%$ : } \\
\hline - set eggs & 59.5 & 21.35 & 0.472 & -0.086 & 67.0 & 19.61 & 0.032 & 0.028 \\
\hline - fertile eggs & 68.3 & 18.56 & 0.383 & -0.100 & 71.8 & 17.27 & 0.154 & -0.079 \\
\hline
\end{tabular}

* - the first generation descending from toms (sires) sclected with regard to reproductive traits 
On the basis of an individual control of hens' performance in $G_{12}$ and $G_{13}$, arithmetic means and standard deviations in 9 analysed traits were calculated (Table 1). Using the hierarchic analysis of variance and covariance according to the model provided by Żuk (1989), heritability coefficients $\left(\mathrm{h}^{2}\right)$ and the so called dam effect values $\left(c^{2}\right)$ as well as genetic $\left(r_{G}\right)$ and phenotypic $\left(r_{p}\right)$ correlations occurring between the investigated traits were used. The calculations were made with the SELECT system (Szewczyk and Brągiel, 1981) based on standardized values including adjustments to the hatch sequence.

The expected breeding gain (BG) in each of the traits $x_{1}, x_{2}$ and $x_{3}$, resulting from the selection of toms, was adopted from the paper by Wawro et al. (1993), and that resulting from the selection of hens was calculated by means of the formula:

$$
\mathrm{BG}=\frac{\mathrm{ixs \times h^{2 }}}{2 \sqrt{\mathrm{h}}}
$$

where: $\mathrm{i}$ - selection intensity coefficient, $\mathrm{s}$ - standard deviation, 2 (two) in the denominator of this formula means that dams will pass to their progeny only half of the hereditary assumptions, $\mathrm{n}$ - the number of traits included in the selection program.

In $\mathrm{J}-44$, the ,selection index of reproductive traits" comprised 9 traits (Jankowski, 1989). The formula for the BG assumed the form:

$$
\mathrm{BG}=\frac{\mathrm{ixs \times h^{2 }}}{6}
$$

The achieved breeding gain (BG') in $G_{13}$ and $G_{12}$ was calculated from the difference between the average value of a given trait:

where: $\mathrm{k}-\mathrm{k}_{\mathrm{n}}$ trait.

$$
B G_{k}^{\prime}=\bar{x}_{k G_{13}}-\bar{x}_{k G_{12}}
$$

\section{RESULTS AND DISCUSSION}

Among the traits, the values of which underwent favourable changes due to the conducted breeding work, worth mentioning are, first of all, egg fertility and hatchability from fertile eggs. They increased, on the average, by $5 \%$ in $\mathrm{G}_{13}$ compared to $G_{12}$ (Table 1 ). The average number of eggs laid by one hen increased by 10 eggs in the period of these two generations under analysis. However, it should be emphasized that such traits as egg production, egg fertility and 
hatchability are included among the low-heritable ones and are highly influenced by the environment (Nestor et al., 1972; Arthur and Abplanalp, 1975; Jankowski, 1989; Wawro et al., 1993). Even small changes in the environmental conditions between two successive turkey generations can bring about a considerable decrease in the value of these reproductive traits.

Estimated values of heritability coefficients of the analysed hen traits (Table 1) did not deviate from those given by other authors (Nestor et al., 1972; Arthur and Abplanalp, 1975; Jankowski, 1989; Wawro et al., 1993). The reproductive maturity age in $\mathrm{G}_{12}$ was characterized by the highest heritability $\left(h^{2}=0.758\right)$ whereas hatchability from the eggs set in $G_{13}\left(h^{2}=0.032\right)$ - the lowest. For all the traits, the heritability coefficients values estimated in $G_{12}$ were higher than in $G_{13}$. This may have been caused by a decrease in the additive genetic variability due to the selection methods used, since the largest differences in $\mathrm{h}^{2}$ values were found in the traits included in the toms index. The decrease in heritability coefficient values in $G_{13}$ could also be influenced by an increase in the environmental variance appearing in the denominator of the formula for estimating $\mathrm{h}^{2}$. Another explanation of this phenomenon may be a revaluation of $h^{2}$ in $G_{12}$. However, in such a case the $\mathrm{c}^{2}$ values (the so called dam effect) of the analysed hen traits in $G_{13}$ should significantly differ from $\mathrm{c}^{2}$ of these traits in $\mathrm{G}_{12}$. No such dependence in $\mathrm{c}^{2}$ values in hen generations 12 and 13 has been found (Table 1). It was only the influence of dams on the eggs mass in $\mathrm{G}_{13}\left(\mathrm{c}^{2}=0.263\right)$ that deviated most from $\mathrm{c}^{2}$ of this trait in $G_{12}(0.074)$. In other cases the estimated $c^{2}$ values were small, which is in accordance with earlier research by Jankowski (1989). He has also found that in strain J-44 sires had a larger impact on daughters' egg production than dams did.

The values of coefficients of phenotypic correlations and partly those of genetic correlations underwent slight changes between the analysed turkey hens generations (Table 2). The body weights of hens both at 30 and 56 weeks generally showed little interdependence with investigated reproductive traits. A considerable phenotypic correlation has been found only between the traits closely interrelated biologically with one another. Thus, $r_{p}$ between a hatchability from set eggs and hatchability from fertile eggs was 0.85 . A slightly lower phenotypic correlation has been found between the number of laid eggs and the number of egg laying days $\left(r_{p}>0.6\right)$.

Similar trends have also been found with regard to the values of coefficients of genetic correlations $\left(r_{\mathrm{G}}\right)$ between the traits included in the genetic improvement program in the studied strain (Table 2). It should be stressed that there were a large number of cases of not estimating $r_{\mathrm{G}}$ between quantitative leap traits (assuming only integer values) and expressed as a percentage in spite of standardization of the values of these traits into so called "W indices" (Szewczyk and Brągiel, 1989). 
TABLE 2

Coefficients of genetic correlation $-r_{G}$ (above the diagonal) and of phenotypic correlation $-r_{p}$ (below the diagonal) between analysed traits in generations 12 and 13

\begin{tabular}{|c|c|c|c|c|c|c|c|c|c|c|c|}
\hline \multirow{2}{*}{ No } & \multirow{2}{*}{ Trait } & \multirow{2}{*}{$\begin{array}{l}\text { Gene- } \\
\text { ration }\end{array}$} & \multicolumn{9}{|c|}{ Number of trait } \\
\hline & & & 1 & 2 & 3 & 4 & 5 & 6 & 7 & 8 & 9 \\
\hline & Body weight at theage: & & & & & & & & & & \\
\hline \multirow[t]{2}{*}{1} & -30 weeks & 12 & - & .719 & -.230 & -.836 & -.386 & $\mathrm{~N}$ & $\mathrm{~N}$ & .135 & $\mathrm{~N}$ \\
\hline & & 13 & - & .913 & .161 & -.257 & -.415 & $\mathrm{~N}$ & $N$ & $\mathrm{~N}$ & .266 \\
\hline \multirow[t]{2}{*}{2} & -56 weeks & 12 & .579 & - & -.185 & -.550 & -.315 & .512 & $\mathrm{~N}$ & .108 & $\mathrm{~N}$ \\
\hline & & 13 & .465 & - & $\mathbf{N}$ & -.479 & .016 & $\mathrm{~N}$ & $\mathbf{N}$ & $\mathrm{N}$ & $\mathrm{N}$ \\
\hline \multirow[t]{3}{*}{3} & Reproductive maturity & & & & & & & & & & \\
\hline & age & 12 & -.031 & -.150 & - & .437 & .787 & -.178 & $\mathrm{~N}$ & .331 & $\mathrm{~N}$ \\
\hline & & 13 & .042 & -.103 & - & .599 & 1.190 & $\mathrm{~N}$ & $\mathrm{~N}$ & $\mathrm{~N}$ & .048 \\
\hline \multirow[t]{2}{*}{4} & Number of eggs & 12 & -.220 & -.172 & .329 & - & .853 & $\mathrm{~N}$ & $\mathrm{~N}$ & $\mathrm{~N}$ & $\mathrm{~N}$ \\
\hline & & 13 & -.099 & -.152 & .345 & - & .705 & $\mathrm{~N}$ & $\mathrm{~N}$ & $\mathrm{~N}$ & -.335 \\
\hline \multirow[t]{2}{*}{5} & Number of laying days & 12 & -.100 & -.076 & .606 & .627 & - & .065 & $\mathrm{~N}$ & .177 & $\mathrm{~N}$ \\
\hline & & 13 & -.086 & -.175 & .649 & .687 & - & $\mathrm{N}$ & $\mathrm{N}$ & $\mathrm{N}$ & -.243 \\
\hline \multirow[t]{2}{*}{6} & Egg weight & 12 & .223 & .162 & -.027 & -.053 & .052 & - & $\mathbf{N}$ & .360 & $\mathrm{~N}$ \\
\hline & & 13 & .114 & .085 & .015 & .027 & .053 & - & $\mathrm{N}$ & .063 & $\mathrm{~N}$ \\
\hline \multirow[t]{3}{*}{7} & Egg fertility & 12 & -.031 & -.069 & .007 & -.051 & -.087 & -.016 & - & $\mathrm{N}$ & $\mathrm{N}$ \\
\hline & & 13 & -.032 & -0.53 & .071 & -.005 & -.026 & .012 & - & $\mathrm{N}$ & $\mathrm{N}$ \\
\hline & Hatchability from: & & & & & & & & & & \\
\hline \multirow[t]{2}{*}{8} & - set eggs & 12 & -.095 & -.098 & .038 & .055 & -.051 & -.052 & .492 & - & $\mathrm{N}$ \\
\hline & & 13 & -.125 & -.043 & .054 & -.002 & .024 & -.028 & .461 & - & $\mathrm{N}$ \\
\hline \multirow[t]{2}{*}{9} & - fertile eggs & 12 & -.133 & -.121 & .040 & .066 & .017 & .066 & .200 & .856 & - \\
\hline & & 13 & -.125 & -.032 & .032 & .073 & .028 & -.056 & .194 & .880 & - \\
\hline
\end{tabular}

$\mathrm{N}$ - unestimable values

critical values $\boldsymbol{I}_{\mathrm{p}}$ for level $\mathrm{P} \leqslant 0.05-0.062$ in generation 12 and 0.075 in generation 13

As it was mentioned in the part „Material and Methods”, the basis for the selection of toms to selection flocks was the result of the estimating the total breeding value (by means of the index) of their sires based on the performance of dams and, on the average, five sisters and six half-sisters (Wawro et al., 1993). The selection index for toms includes three traits: the number of eggs $\left(\mathrm{x}_{1}\right)$, eggs fertility $\left(\mathrm{x}_{2}\right)$ and hatchability from fertile eggs $\left(\mathrm{x}_{3}\right)$; this is why only these traits were taken into consideration in the analysis of breeding gain of $\mathrm{J}-44$ strain turkey hens. It also results from the fact that the economic effectivity of production commercial turkeys is determined, to a high degree, by reproduction results in parental flocks. 
TABLE 3 A formation of expected (BG) and achieved (BG') breeding gain in the traits included in the selection index for toms

\begin{tabular}{lccccc}
\hline & \multicolumn{3}{c}{$B G$} & \multicolumn{2}{c}{$B G^{\prime}$} \\
\cline { 2 - 5 } Traits & resulting & from & selection & \\
\cline { 2 - 5 } & toms & hens & total & $\mathrm{G}_{13}-\mathrm{G}_{12}$ & $\mathrm{G}_{13}$ expressed in \% $\mathrm{G}_{12}$ \\
\hline Number of eggs & $1.96^{\mathrm{a}}$ & 2.03 & 3.99 & 10.2 & 111.64 \\
Egg fertility, \% & $2.03^{\mathrm{a}}$ & 0.45 & 2.48 & 5.0 & 105.73 \\
Hatchability from & $1.61^{\mathrm{a}}$ & 0.95 & 2.56 & 3.5 & 108.30 \\
fertilized eggs, \% & & & & & \\
\hline
\end{tabular}

a - values from the paper by Wawro et al. (1993)

The analysis of the results (Table 3 ) indicates a very great breeding gain (BG) in all three traits included in the toms selection index. It was, first of all, determined by a high selection intensity and a relatively high accuracy of the estimating of toms breeding value (Wawro et al., 1993), i.e. the estimating of the amount of additive genes determining the $\mathrm{x}_{1}, \mathrm{x}_{2}$, and $\mathrm{x}_{3}$ traits. A larger expected breeding gain $(\mathrm{BG})$ in the number of eggs as a result of hens selection (BG $=2.03)$ than that of toms selection $(B G=1.96)$ is the effect of a relatively high value of $h^{2}(0.427)$ in the 12 th generation. However, while constructing the toms selection index (Wawro et al., 1993), a significantly lower heritability of this trait was adopted $\left(\mathrm{h}^{2}=0.15\right)$, determined on the basis of many years' investigations of J-44 strain birds (Jankowski, 1989).

The achieved breeding gain (BG'), being the result of an actual improvement of hereditary assumptions for turkeys and possible improvement of the environmental conditions and genetic-environmental interaction, was much greater than expected, and amounted to $10.2 \mathrm{eggs}, 5.0 \%$ of egg fertility, and $3.5 \%$ of hatchability from fertile eggs (Table 3 ). Taking into account a considerable increase in the body weight of turkey hens in $\mathrm{G}_{12}$ and $\mathrm{G}_{13}$ (Table 1) in comparison with previous generations (Jankowski, 1989; Baran, 1993,), it can be concluded that the breeding methods used in this strain (breeding value estimation, selection and mating) turned out to be efficient. This conclusion is proved by the results of the research by McCartney et al. (1968), Nestor (1971, 1977a, 1977b, $1980,1984)$ and Nestor et al. (1985) conducted in various turkey strains. These authors, through selecting turkeys for increasing the body weight of different age birds, obtained an increase in the value of this trait accompanied by a worsening of egg production, egg fertility or hatchability. Conducting, in turn, a selection aimed at increasing the values of reproductive performance, they were often obtaining a decrease in the turkeys' body weight. 


\section{CONCLUSIONS}

In the breeding work on the J-44 strain, the used toms selection index, which included reproductive traits appearing in the phenotype only in hens, in addition to the index of female reproductive traits, improved the efficiency of selection and enabled to increase breeding gain in the number of eggs and their fertility as well as hatchability.

\section{REFERENCES}

Arthur J., Abplanalp H., 1975. Linear estimates of heritability and genetic correlation for egg production, body weight, conformation and egg weight of turkeys. Poultry Sci. 54, 11-23

Baran S.T., 1993. Inbreed application in the program of genetic improvement of turkeys (in Polish). University of Agriculture and Technology, $\mathrm{PhD}$ thesis Olsztyn (Manuscript)

Faruga A., Jankowski J., Misiarczyk E., 1986. Technology of rearing and utilization of Wama turkey parental flocks (in Polish). University of Agriculture and Technology, Olsztyn (Manuscript)

Jankowski J., 1989. Response of four turkey populations to applied methods of breeding (in Polish). Acta Acad. Agric. Techn. Olst., Zoot. 31, Suppl. F, 3-56

McCartney M.G., Nestor K.E., Harvey W.R., 1968. Genetics of growth and reproduction in the turkey. 2. Selection for increased body weight and egg production. Poultry Sci. 47, 981-990

Nestor K.E. 1971. Genetics of growth and reproduction in the turkey. 3. Further selection for increased egg production. Poultry Sci. 50, 1672-1682

Nestor, K.E., 1977a, Genetics of growth and reproduction in the turkey. 5. Selection for increased body weight alone and in combination with increased egg production. Poultry Sci. 56, 337-347

Nestor K.E., 1977b. The influence of a genetic change in egg production, body weight, fertility or response to cold stress on semen yield in the turkey. Poultry Sci. 56, 421-425

Nestor K.E. 1980. Genetics of growth and reproduction in the turkey. 7. Relationship of total egg production, intensity of lay, broodiness and body weight. Poultry Sci. 59, 1385-1394

Nestor K.E. 1984. Genetics of growth and reproduction in the turkey. 9. Long-term selection for increased 16-week body weight. Poultry Sci. 63, 2114-2122

Nestor K.E., Bacon W.L., Saif Y.M., Renner P.A., 1985. The influence of genetic increases in shank width on body weight, walking ability and reproduction of turkeys. Poultry Sci. 64, 2248-2255

Nestor K.E., Brown K.T., Weaver C.R., 1972. Egg quality and poult production in turkeys. 2. Inheritance and relationship among traits. Poultry Sci. 51, 147-158

Szewczyk A., Brągiel B., 1981. Electronic data processing in poultry raising - SELECT system (in Polish). Prace Bad. Zakł. Hod. Drobiu, IZ Kraków, 9, 33-51

Wawro K., Jankowski J., Faruga A., 1993. Estimating of breeding value of toms as regards their reproductive traits (in Polish). Prz. hod., Zesz., Nauk., 8, Chów i Hodowla Drobiu, 105-112

Żuk B., 1989. Applied Biometry (in Polish). PWN, Warszawa 


\section{STRESZCZENIE}

\section{Doskonalenie cech reprodukcyjnych indyczek $\mathrm{z}$ uwzględnieniem selekcji indorów}

Badaniami objęto 1210 indyczek z 12 pokolenia $\left(F_{12}\right)$ i 737 indyczek z 13 pokolenia $\left(F_{13}\right)$ rodu matecznego żeńskiego J-44. Ojcowie indorów wybieranych do stadek selekcyjnych w $F_{12}$ i $F_{13}$ byli oceniani za pomocą indeksu selekcyjnego, uwzględniającego cechy reprodukcyjne ich krewnych żeńskich: matek, sióstr i półsióstr. Indyczki z kolei wybierano uwzględniając wyniki oceny wartości użytkowej i hodowlanej ich matek zgodnie z systemem SELEKT.

Stwierdzono, że zastosowane metody hodowlane zmierzające do zwiększenia wartości cech reprodukcyjnych indyczek rodu J-44 okazały się skuteczne. Realizowany postęp hodowlany wyniósł 10,2 jaja, 5,0\% zapłodnienia jaj oraz 3,5\% wylęgu piskląt zdrowych z jaj zapłodnionych. 